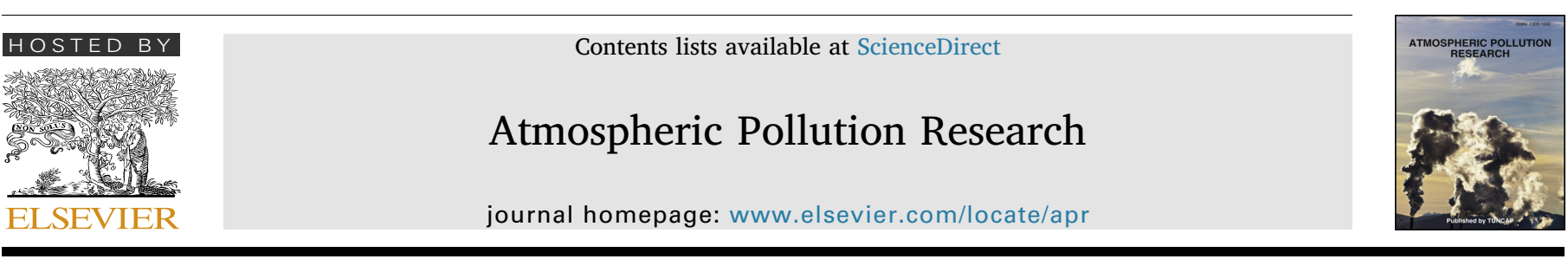

\title{
Sources of indoor air pollution at a New Zealand urban primary school; a case study
}

\author{
Julie Bennett ${ }^{\mathrm{a}, *}$, Perry Davy ${ }^{\mathrm{b}}$, Bill Trompetter ${ }^{\mathrm{b}}, \mathrm{Yu}_{\text {Wang }}^{\mathrm{c}}$, Nevil Pierse $^{\mathrm{a}}$, Mikael Boulic ${ }^{\mathrm{c}}$, \\ Robyn Phipps ${ }^{\mathrm{c}}$, Philippa Howden-Chapman ${ }^{\mathrm{a}}$ \\ ${ }^{a}$ Department of Public Health, University of Otago, Wellington, New Zealand \\ ${ }^{\mathrm{b}}$ GNS Science, Lower Hutt, New Zealand \\ c School of Engineering and Advanced Technology, Massey University, Auckland, New Zealand
}

\section{A R T I C L E I N F O}

\section{Keywords:}

Air quality

Air pollution

Schools

Children

Source apportionment

\begin{abstract}
A B S T R A C T
Children are particularly vulnerable to the health effects of air pollution and as they spend a large proportion of time at school, this is an important environment for children's exposure to air pollution. Understanding the factors that influence indoor air quality in schools is critical for the assessment and control of indoor air pollution. This study analysed the concentration and sources of air pollution at an urban primary school (5-11 years) in Wellington, the capital of New Zealand. Over a three-week period during spring, indoor measures of particulate matter $\left(\mathrm{PM}_{2.5}, \mathrm{PM}_{10}\right)$, temperature, humidity, carbon dioxide $\left(\mathrm{CO}_{2}\right)$ and nitrogen dioxide $\left(\mathrm{NO}_{2}\right)$ were taken and hourly air particulate matter samples $\left(\mathrm{PM}_{2.5}, \mathrm{PM}_{10-2.5}\right)$ were collected inside and outside for elemental speciation analysis. Indoor $\mathrm{PM}_{10}$ concentrations during the school day were significantly $(\mathrm{p}<0.001)$ higher than outdoor concentrations 30.1 (range 10.0-75.0, SD 1.9) $\mu \mathrm{g} \mathrm{m}^{-3}$ c.f. 8.9 (range < 1.0-35.0, SD 6.8) $\mu \mathrm{g} \mathrm{m}^{-3}$. Elemental analysis and receptor modelling of PM samples showed that indoor $\mathrm{PM}_{10}$ was primarily composed of crustal matter (soil) elements, possibly brought in on children's footwear. The primary driver of indoor $\mathrm{PM}_{2.5}$ was from the infiltration of outdoor pollutants inside, with by-products of motor vehicle emissions the main contributor to indoor $\mathrm{PM}_{2.5}$. There is a need for mitigation strategies to reduce exposure to indoor air pollution at school, such as improved cleaning methods, reducing the use of carpet in schools and improved ventilation. The findings from this study will be applicable to many other schools and public buildings with high foot traffic.
\end{abstract}

\section{Introduction}

Indoor air quality is a growing concern in both developing and developed countries. Recent assessments have placed indoor air pollution as the nineth largest Global Burden of Disease risk (Forouzanfar et al., 2015). People are estimated to spend around $90 \%$ of their time indoors and are therefore exposed to higher concentrations of indoor air pollutants than those outdoors (Kostinen et al., 2008; Almeida et al., 2011; de Gennaro et al., 2014). Children are more vulnerable to the effects of air pollution than adults as they breathe more rapidly, their lungs are larger in relation to their body size and they are not fully developed, allowing pollutants to become more concentrated in their systems (Bennett et al., 2008; Fuentes-Leonarte et al., 2009).

Like other countries, children in New Zealand spend the second largest proportion of their day indoors at school, making classrooms a major contributor to children's exposure to air pollution. The recognition that toxic pollutants can have a serious and long-lasting impact on children has recently led to a significant body of work on health-related exposures in schools (Jacobs et al., 2014; Morgan et al., 2014; Sofuoglu et al., 2011; Stranger et al., 2008; Chen et al., 2014).

The health effects of poor air quality are far reaching with the most prominent effects seen on the respiratory and cardiovascular systems (Clausen et al., 2009; Simoni et al., 2010; Annesi-Maesano et al., 2013; Franklin et al., 2015; Brook, 2008). Respiratory conditions, such as asthma are a major cause of hospitalisation and school absenteeism in New Zealand and other western countries (Moonie et al., 2006; Daisey et al., 2003; Taras and Potts-Datema, 2005). Poor air quality can aggravate asthma symptoms (McConnell et al., 2010) and led to the development of asthma (MacIntyre et al., 2014). While the link between pulmonary diseases and air pollution is well established, the link with cardiovascular conditions has had less attention in research literature. However, it is becoming clear, that the effects on cardiovascular health

\footnotetext{
Peer review under responsibility of Turkish National Committee for Air Pollution Research and Control.

* Corresponding author. Department of Public Health, University of Otago, 23 Mein St, Newtown, Wellington 6242, New Zealand.

E-mail address: Julie.Bennett@otago.ac.nz (J. Bennett).
} 
may be as significant as on lung health (Uzoigwe et al., 2013).

As well as health effects poor indoor air quality impacts students cognitive function and development, comfort, concentration and performance (Mendell and Heath, 2005; Porta et al., 2016). One study reported that 7-to 10-year old children attending schools exposed to high levels of traffic related air pollution had slower cognitive development than children attending lower polluted schools (Sunyer et al., 2015). A recent study in Barcelona reported that children aged 7-to-11 years old exposed to air pollution while at school had increased behavioural problems (Forns et al., 2016). One study looked at air quality in 51 schools in Portugal, reported that high levels of carbon dioxide $\left(\mathrm{CO}_{2}\right)$ as a result of breathing and an indication of poor ventilation, had an impact on cognitive function and therefore learning (Ferreira and Cardoso, 2014).

High ventilation rates in classrooms have been shown to improve children's health and school attendance (Mendell et al., 2013; de Gennaro et al., 2014). Most (90\%) classrooms in New Zealand are designed to be naturally ventilated through windows (McIntosh, 2011). Existing school buildings in New Zealand have no regulation around ventilation; however, new buildings require a minimum ventilation rate of $8 \mathrm{Ls}^{-1}$ if mechanical ventilation is present (CEN Standard EN15251, 2007; Standards Association of NZ, 1990; ASHRAE, 1989). Recently the New Zealand Ministry of Education introduced regulations for carbon dioxide $\left(\mathrm{CO}_{2}\right)$ concentrations (not to exceed $1500 \mathrm{ppm}$ average and $3000 \mathrm{ppm}$ peak during the teaching day) as a proxy for ventilation rates in newly built or upgraded schools (Ministry of Education, 2017).

Classroom air quality is affected by indoor sources and through infiltration of outdoor sources, with indoor particulate matter (PM) concentrations shown to be highly correlated with outdoor levels (Raysoni et al., 2011). This is of concern as schools and childcare facilities are often located in close proximity to busy roads that have elevated levels of traffic-related air pollution that peak while the children are at school (Sunyer et al., 2015; Amram et al., 2011).

Previous indoor air quality studies are generally based on particle mass concentrations, without the identification of the main pollutant sources (Kulkarni and Grigg, 2008; Nazaroff, 2004). An important first step in reducing children's exposure to pollutants indoors at school is a need for more accurate methods to disentangle source contributions in the indoor environment (Nazaroff, 2004; Stanek et al., 2011; Tunno et al., 2016). Once there is an understanding of the indoor pollution sources, mitigation measures can be more targeted towards reducing children's exposure to air pollution and improve health outcomes.

This study reports on the composition, origin and contributions to $\mathrm{PM}_{2.5}, \mathrm{PM}_{10}$ and $\mathrm{NO}_{2}$ concentrations in a classroom and differentiates the particulate matter which is generated within a classroom from that which infiltrated from the outdoor environment and their impact on indoor air quality. Receptor modelling techniques were used on the particulate matter composition data to determine the sources of air pollution and the relative contributions of resolved sources to both indoor and outdoor air quality at a New Zealand urban primary school. In addition temperature and humidity levels were monitored alongside $\mathrm{CO}_{2}$, which was used to estimate ventilation rates.

\section{Methods}

\subsection{School location and classroom characterisation}

The primary school chosen for this study was located in Wellington, New Zealand. The urban area of Wellington is the third largest in New Zealand, with approximately 250,000 people. Wellington has an average wind speed of over $26 \mathrm{~km} / \mathrm{h}$ (Mathiesen, 2015) and is located adjacent to a harbour. Fig. 1a shows that the school is situated $1.5 \mathrm{~km}$ from the harbour and the classroom monitored was located approximately $38 \mathrm{~m}$ away from a busy intersection on a main arterial road. The main arterial road has approximately 16,000 vehicles travel along it daily (Personal Communication).
Fig. 1b provides photos of the outside monitoring location on a small grassed area adjacent to the classroom (within $3 \mathrm{~m}$ ) with instrumentation contained inside a purpose built enclosure and the sampling head set at two metres high (about the height of the classroom windows). Fig. 1c shows the inside of the classroom monitored, which was typical of a New Zealand 1970's single-storied prefabricated weatherboard building. This type of classroom was designed for temporary use however many are still in use throughout the country. The walls and ceiling were uninsulated and the floor was suspended timber with carpet. The roof was corrugated mild steel with a central ridge beam. Cross ventilation occurred if windows were opened on both sides. Heating was provided by an electric fan heater. All measurements were undertaken over a three-week period during spring (10th to 31st October 2016).

Throughout the day approximately 25 children aged 8-to-9 years occupied the classroom, which was eight meters by six metres and had a volume of $168 \mathrm{~m}^{3}$. The classroom had a wooden teachers' desk and four communal wooden tables for the children to work. Fifteen plastic chairs were available for use with children often working while sitting on the floor or at a lower kneeling table. The door of the classroom was left open as children often choose to work on the outside covered deck area, which attached the classroom to three other prefabricated classrooms. A whiteboard was used for teaching and the walls were covered in artworks created by the children.

\subsection{Instrumentation}

TSI Dusttrak II Aerosol Monitors (Model 8530, TSI Inc., MN, USA) measured indoor $\mathrm{PM}_{2.5}$ and $\mathrm{PM}_{10}$ from the classroom. Twenty-four hour continuous measurement was recorded at 5-min intervals. The Dusttrak air flows were calibrated according to ISO 12103-1 AI Test Dust (Arizona Dust). The equipment was factory calibrated. A TSI Q-Trak IAQ monitor (Model 8552, TSI Inc., MN, USA) continuously measured indoor temperature, humidity and $\mathrm{CO}_{2}$ which were recorded at two minute intervals. The pre-fieldwork had been done to check the Q-Trak measurements. Nitrogen dioxide $\left(\mathrm{NO}_{2}\right)$ was measured inside the classroom alongside the other indoor instrumentation with a low-cost metal oxide type sensor (e2v MiCS-5525 sensor in the Air Quality Egg, Wicked Device, Ithaca, NY, USA. The Dusttrak Q-Trak and $\mathrm{NO}_{2}$ sensor were placed in a custom-made support structure. The support structure was placed at the side of a classroom in a location that minimised disruption to classroom activities. The probes were placed at the height of $1.1 \mathrm{~m}$ (the average breathing height of the children).

An E-BAM (Met One Instruments, Inc, OR, USA) measured continuous $\mathrm{PM}_{10}$ concentrations outdoors. The E-BAM air flows were calibrated pre and post sampling (Gilian Gilibrator-2 NIOSH Primary Standard Air Flow Calibrator, Sensidyne LP) and mass attenuation of the E-BAM calibrated with standard calibration foils.

Hourly time-integrated samples of size segregated coarse ( $\left.\mathrm{PM}_{2.5-10}\right)$ and fine $\left(\mathrm{PM}_{2.5}\right)$ particulate matter samples were collected using a modified Streaker sampler (PIXE International Corporation, USA). The Streaker sampler has previously been described in detail (Zhou et al., 2016; Annegarn et al., 1988) and used in a number of studies (Filippi et al., 1999; D'Alessandro et al., 2004). Briefly, the Streaker sampler consists of a pre-impactor that removes particles larger than $\mathrm{PM}_{10}$ from the incoming air flow, a thin Kapton foil that collects coarse $\left(\mathrm{PM}_{2.5-10}\right)$ particles through impaction and a Nucleopore filter $(0.4 \mu \mathrm{m}$ pore size) that collects fine $\left(\mathrm{PM}_{2.5}\right)$ particles. Each discrete $\mathrm{PM}_{2.5-10}$ and $\mathrm{PM}_{2.5}$ sample was deposited in a clearly defined $8 \mathrm{~mm}$ by $2 \mathrm{~mm}$ rectangular area on a rotatable filter. An electronic control system regulated the Streaker sampler pneumatics mass flow (1 L per minute) and stepper motor rotation of the filter between each user-defined sampling period. The hourly samples were collected with discrete spacing between each deposit to ensure that each deposit only consisted of particulate matter collected during the intended hour. A total of 60 samples (representing $60 \mathrm{~h}$ ) were collected on each filter. 

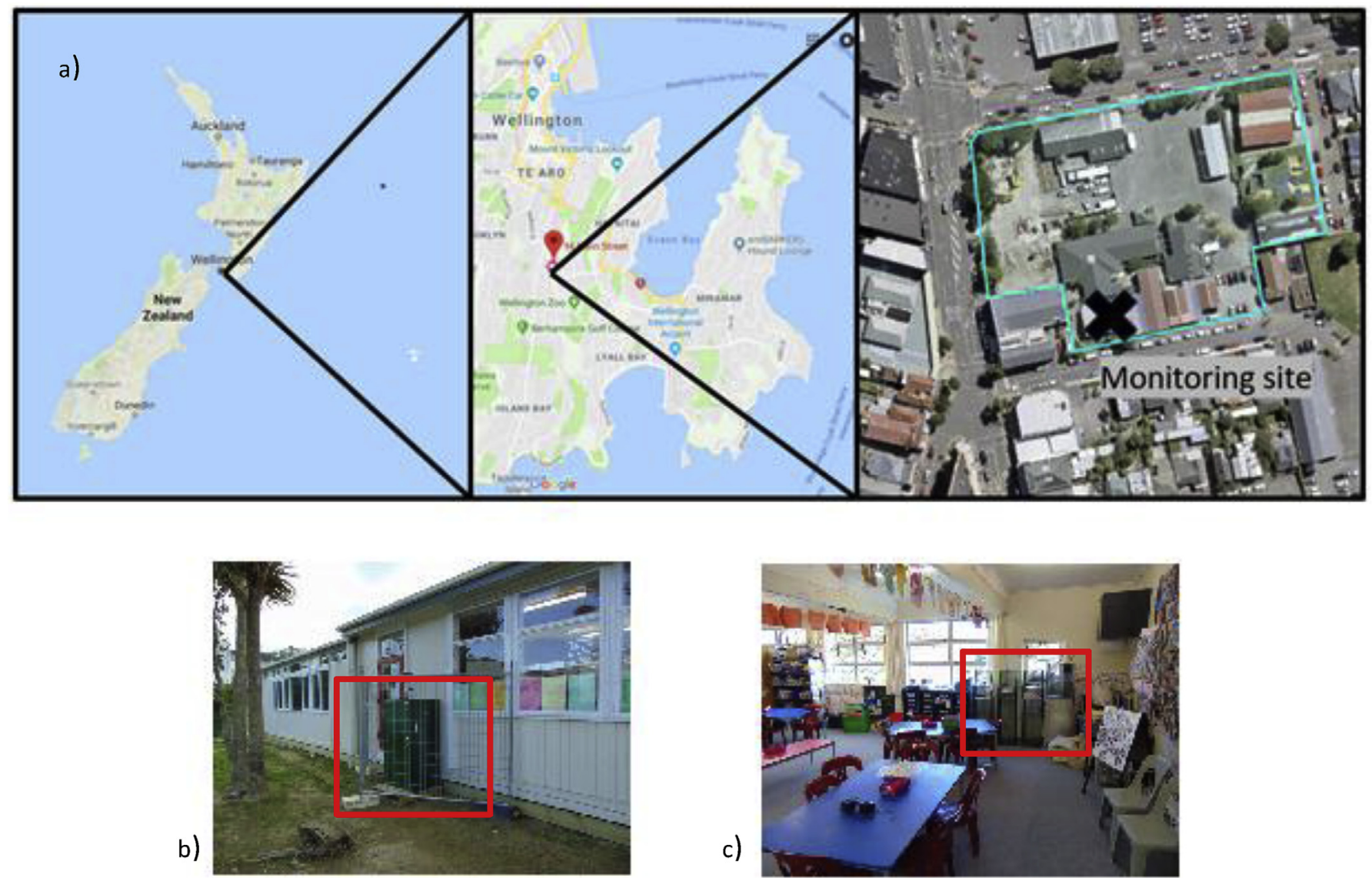

c)

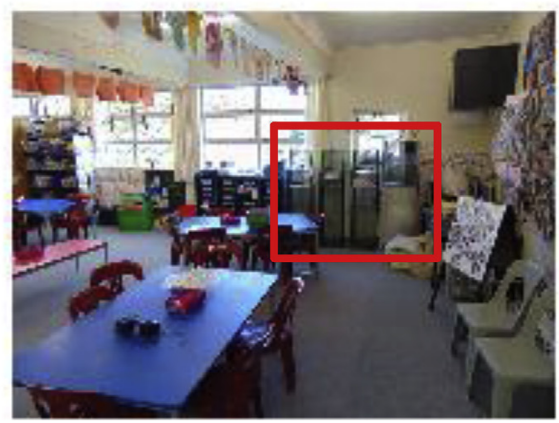

Fig. 1. Location of school. a) Location of Wellington within New Zealand and the school within Wellington. b) outdoor monitoring set-up. c) indoor monitoring setup.

The Streaker samplers were installed both inside (alongside the other instrumentation) and outside the classroom (using the same enclose as the E-BAM) and set to collect hourly samples. Overall, approximately 1000 samples (500 coarse $\mathrm{PM}_{2.5-10}$ and 500 fine $\mathrm{PM}_{2.5}$ ) were collected from each site (indoors and outdoors), representing $1000 \mathrm{~h}$ of sampling. Previous work has shown that subsequent co-located monitoring gives good agreement between hourly average concentrations for the E-BAM, Dusttrak and Streaker sampler devices ( $\mathrm{r} 2 \geq 0.70$ ) over a one week period (Trompetter et al., 2018). As an individual gravimetric (weighing) analysis for each PM deposit is not possible with 60 samples collected on a single filter the PM mass used was from the continuous monitors (E-Bam and Dustrack) operating alongside the Streaker samplers. The mass concentrations for each element were derived from ion beam analysis (IBA) measurements.

\subsection{Particulate matter sample analysis}

Element concentrations with atomic numbers above ten were measured by IBA at the New Zealand National Isotope Centre operated at GNS Science (Trompetter et al., 2005). IBA is a well-established and internationally accepted method for determining PM elemental composition collected on filters (Landsberger and Creatchman, 1999; Maenhaut and Malmqvist, 2001).

The IBA was performed using a $2.5 \mathrm{MeV}$ proton beam with standards (strontium fluoride $\left[\mathrm{SrF}_{2}\right]$, sodium chloride $[\mathrm{NaCl}]$, chromium [Cr] , nickel [Ni], silicon monoxide [SiO], potassium chloride $[\mathrm{KCl}]$, and aluminum [Al]) run before and after each analytical cycle. A filter blank for each filter wheel was also taken by measuring an undeposited (clean) region of the filter. Spectral X-ray peak deconvolution was performed using Gupix software to calculate element concentrations
(Maxwell et al., 1995). The Gupix software also provides a specific statistical error and limit of detection for each element in each sample and these have been used to provide the uncertainty matrix used in the positive matrix factorization (PMF) analysis. Further details on the IBA techniques used, analytical uncertainties and limits of detection have previously been reported (Ancelet et al., 2012). Black carbon (BC) concentrations, as a combustion source marker were measured by light reflectance in all samples using a M43D Digital Smoke Stain Reflectometer (Ancelet et al., 2011).

\subsection{Receptor modelling using positive matrix factorization (PMF)}

Receptor modelling and apportionment of PM mass by PMF was performed using the EPAPMF program version 5.0.14 in accordance with the User's Guide (Norris et al., 2014). With PMF, sources are constrained to have non-negative species concentrations, no sample can have a negative source contribution and error estimates for each observed point are used as a point-by-point weight. This is a distinct advantage of PMF, since it can accommodate missing or below detection limit data that is a common feature of environmental monitoring (Song et al., 2001). Another advantage of PMF is that PM mass concentrations can be included in the model as another variable and the results are directly interpretable as the covariate PM mass contributions associated with each factor (source). Prior to the PMF analyses, data and uncertainty matrices were prepared in the same manner as previous studies (Polissar et al., 1998; Song et al., 2001). Data screening and the source apportionment were performed in accordance to the protocols and recommendations set out by (Brown et al., 2015). Due to the effect that random analytical noise can have on the receptor modelling process, variables with low signal-to-noise ratios were examined by 

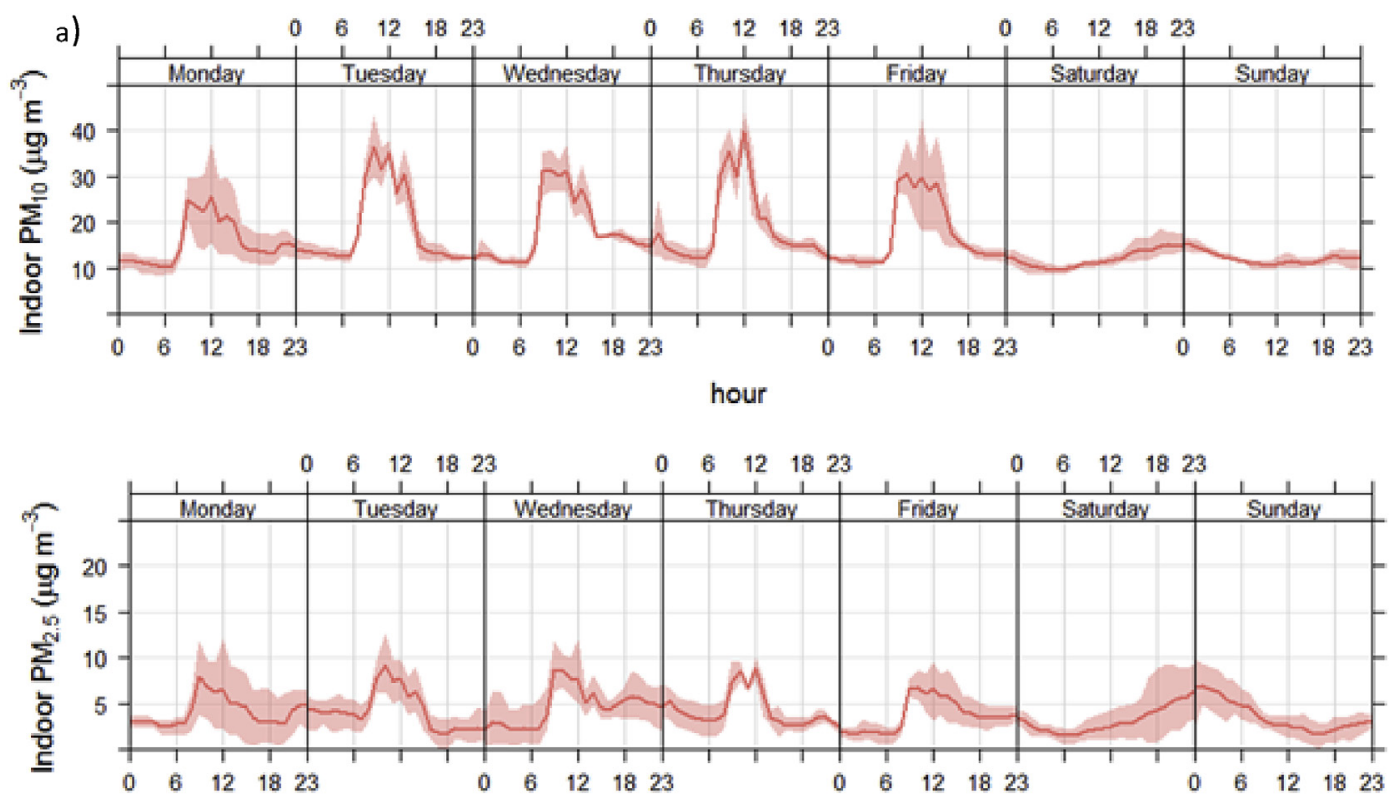

b)
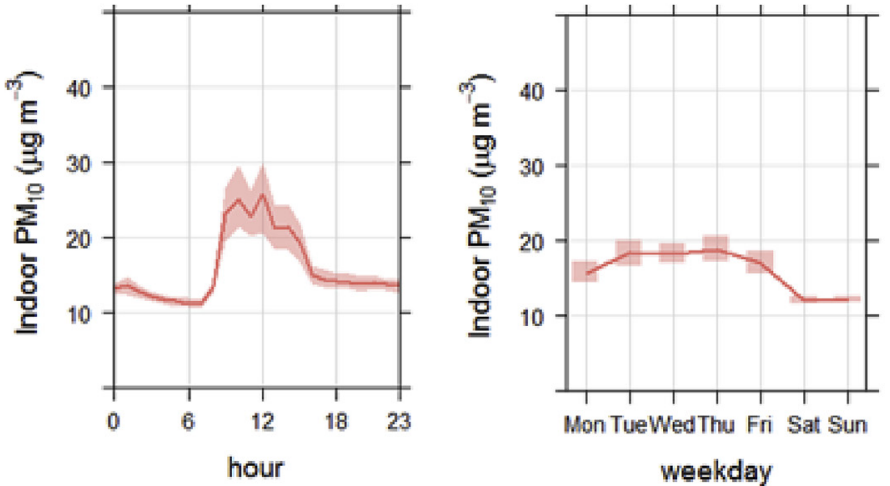

c)
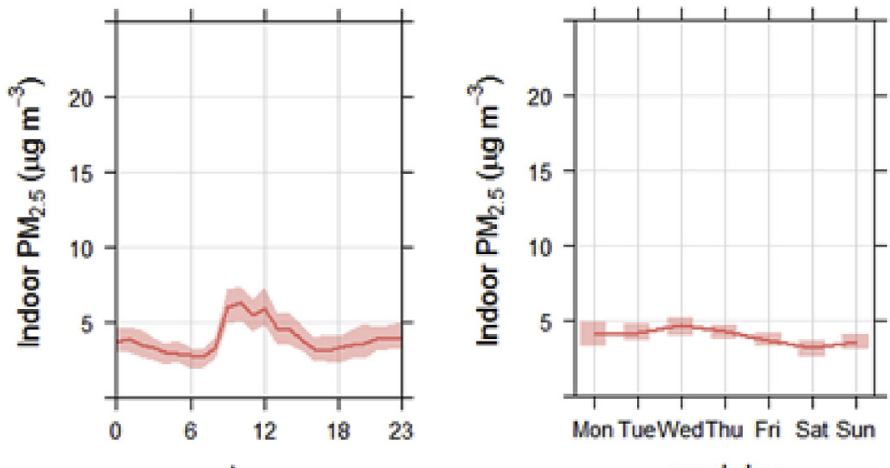

Fig. 2. Indoor $\mathrm{PM}_{2.5}$ and $\mathrm{PM}_{10}$ temporal variation at the school by a) hour of the day and day of the week; b) hour of the day; c) hour of the day; Note that the shaded areas are the $95 \%$ confidence interval in mean concentrations.

alternate inclusion and exclusion in modelling runs and only those variables that could be explained in association with source emissions were included in the final results (Paatero and Hopke, 2009).

\subsubsection{Receptor modelling of elemental concentrations}

Separate PMF analyses were conducted for the indoor and outdoor PM elemental composition datasets. The indoor fine and coarse PM elemental data along with the $\mathrm{NO}_{2}, \mathrm{BC}$ and $\mathrm{PM}$ concentrations were combined into one large data matrix with 516 individual hourly timeintegrated samples covering the entire sampling period. No samples were excluded from the analyses. Since there were measures of both $\mathrm{PM}_{2.5}$ and $\mathrm{PM}_{10}$ mass concentrations for indoors, the PMF analysis was run using both $\mathrm{PM}_{2.5}$ and $\mathrm{PM}_{10}$ (where $\mathrm{PM}_{10}=\mathrm{PM}_{2.5}+\mathrm{PM}_{2.5-10}$ ) elemental concentrations to identify sources contributing to $\mathrm{PM}_{2.5}$ and $\mathrm{PM}_{10}$. PMF was used to explore species relationships and identify factors or source types contributing to indoor PM concentrations during the monitoring period. Subject to the constraints outlined in Section 2.4, multiple PMF model runs were performed choosing fewer and more factors to examine the effect on modelling diagnostics and interpretability of the source profiles coupled with the advantage of high- 


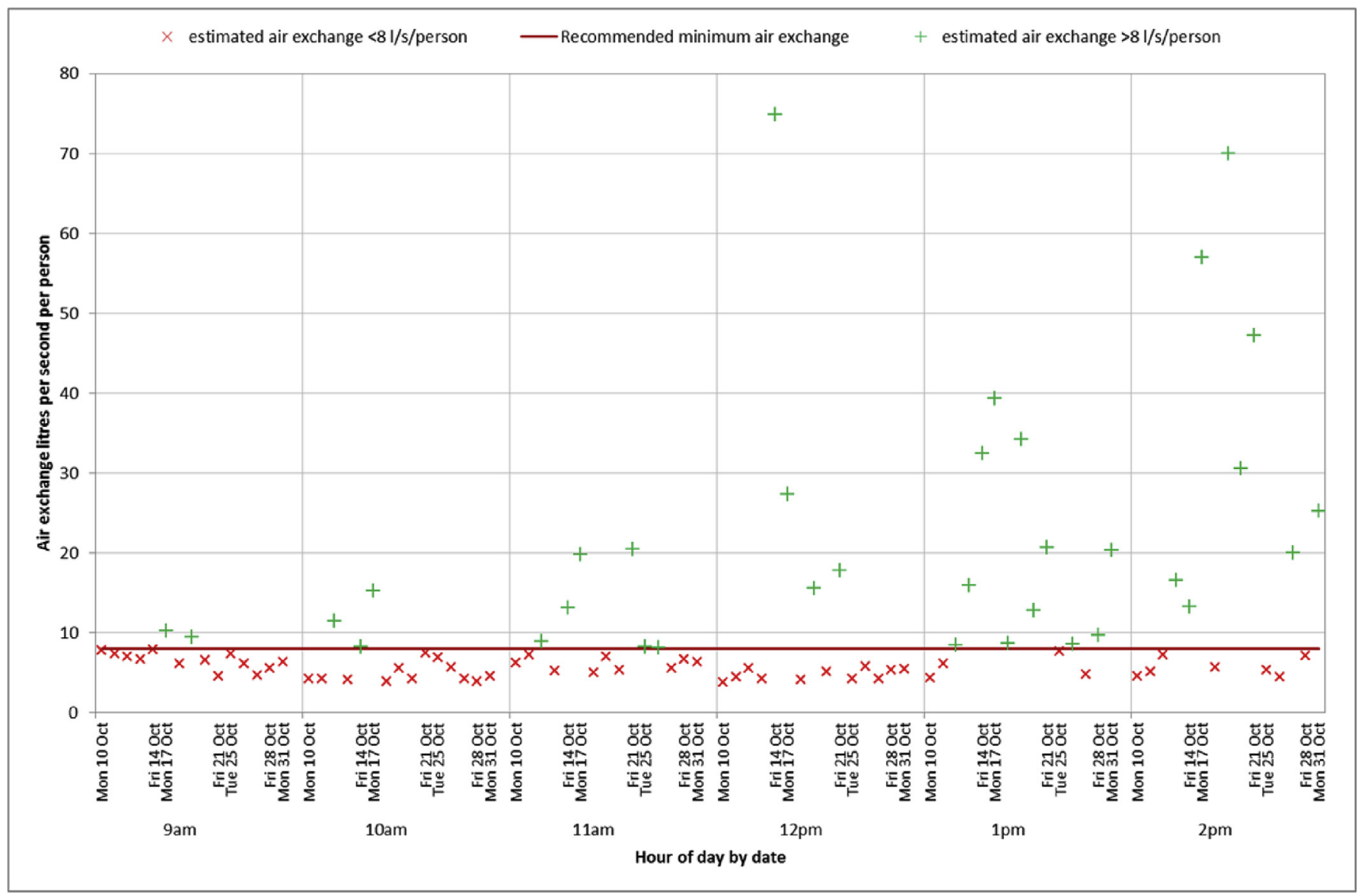

Fig. 3. Ventilation rates calculated using measures of $\mathrm{CO}_{2}$.

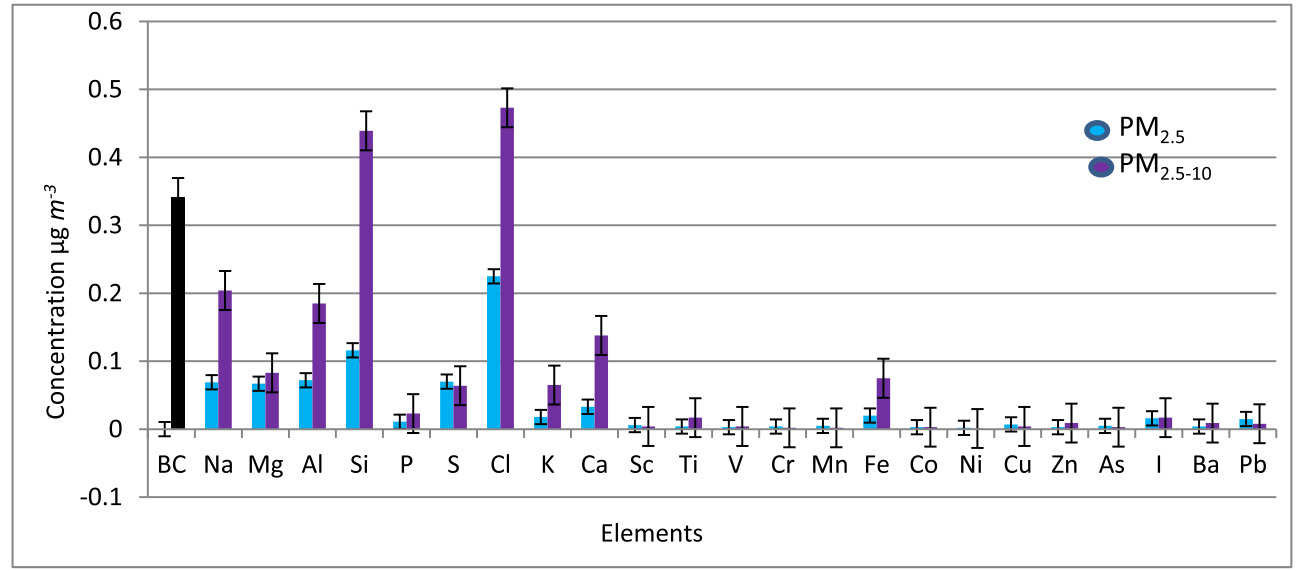

Fig. 4. Average indoor fine $\left(\mathrm{PM}_{2.5}\right)$ and coarse $\left(\mathrm{PM}_{2.5-10}\right)$ elemental compositions.

resolution data to examine the diurnal concentration variations that would be expected for each source type.

The outdoor elemental data was combined with the BC and E-BAM $\mathrm{PM}_{10}$ mass concentration data (420 samples, these were less than for indoor sample sets as two sample runs were missed due to instrument fault) and the PMF analyses run similarly as described for the indoor samples.

\subsection{Ventilation rates}

The ventilation rate was estimated according to the tracer gas $\left(\mathrm{CO}_{2}\right)$ mass balance. The model is valid if the classroom is taken as a single zone model when the net rate of pollutant generation and ventilation rate are constant. In the classroom environment, it can be described as the $\mathrm{CO}_{2}$ generated in classrooms plus the $\mathrm{CO}_{2}$ coming into classrooms from outside minus the $\mathrm{CO}_{2}$ expelled from classroom is equal to the net change of the $\mathrm{CO}_{2}$ concentration. It assumes that the $\mathrm{CO}_{2}$ was wellmixed. In this calculation, the $\mathrm{CO}_{2}$ generation rate of $0.0052 \mathrm{Ls}^{-1}$ for the teacher (two teachers in each classroom) and $0.0029 \mathrm{Ls}^{-1}$ for the pupil (25 pupils in each classroom) was adopted. The ambient $\mathrm{CO}_{2}$ level was $400 \mathrm{ppm}$, the classroom volume was $168 \mathrm{~m}^{3}$. 
Table 1

Highest 10 elemental concentrations indoors and outdoors.

\begin{tabular}{|c|c|c|c|c|c|c|}
\hline \multirow[t]{2}{*}{ Element } & \multicolumn{3}{|l|}{$\mathrm{PM}_{10}$} & \multicolumn{3}{|l|}{$\mathrm{PM}_{2.5}$} \\
\hline & $\begin{array}{l}\text { Indoors average concentration } \\
\mu \mathrm{g} \mathrm{m}^{-3} \text { (range) } \mathrm{SD}\end{array}$ & $\begin{array}{l}\text { Outdoors average concentration } \\
\mu \mathrm{g} \mathrm{m}^{-3} \text { (range) }\end{array}$ & I/O ratio & $\begin{array}{l}\text { Indoors average concentration } \\
\left(\mu \mathrm{g} \mathrm{m}^{-3}\right) \text { (range) } \mathrm{SD}\end{array}$ & $\begin{array}{l}\text { Outdoors average concentration } \\
\left(\mu \mathrm{g} \mathrm{m}^{-3}\right) \text { (range) SD }\end{array}$ & I/O ratio \\
\hline Black carbon & $0.34(0.00-3.62) 0.43$ & $0.18(0.81-1.56) 0.32$ & 1.9 & $0.34(0.0-3.62) 0.43$ & $0.18(0.81-1.56) 0.32$ & 1.9 \\
\hline Sodium & $0.20(0.0-3.19) 0.39$ & $0.16(0.0-1.26) 0.26$ & 1.3 & $0.07(0.0-1.89) 0.22$ & $0.04(0.0-1.00) 0.14$ & 1.8 \\
\hline Magnesium & $0.08(0.0-1.02) 0.13$ & $0.04(0.0-0.30) 0.05$ & 0.5 & $0.07(0.0-0.48) 0.09$ & $0.02(0.0-0.41) 0.05$ & 3.5 \\
\hline Aluminium & $0.19(0.0-2.83) 0.33$ & $0.04(0.0-0.95) 0.07$ & 4.8 & $0.07(0.0-0.82) 0.10$ & $0.03(0.0-0.22) 0.04$ & 2.3 \\
\hline Silicon & $0.44(0.0-6.53) 0.78$ & $0.07(0.0-0.77) 0.10$ & 6.3 & $0.12(0.0-1.56) 0.20$ & $0.01(0.0-0.24) 0.02$ & 12.0 \\
\hline Sulphur & $0.06(0.0-0.59) 0.08$ & $0.04(0.0-0.23) 0.03$ & 1.5 & $0.07(0.0-0.38) 0.07$ & $0.03(0.0-0.12) 0.03$ & 2.3 \\
\hline Chlorine & $0.47(0.0-2.47) 0.47$ & $0.72(0.0-2.69) 0.49$ & 0.7 & $0.23(0.0-1.25) 0.26$ & $0.10(0.0-0.49) 0.11$ & 2.3 \\
\hline Potassium & $0.07(0.0-0.81) 0.10$ & $0.03(0.0-0.27) 0.03$ & 2.3 & $0.02(0.0-0.26) 0.03$ & $0.01(0.0-0.40) 0.03$ & 2.0 \\
\hline Calcium & $0.14(0.0-2.10) 0.26$ & $0.04(0.0-0.25) 0.04$ & 3.5 & $0.03(0.0-0.57) 0.07$ & $0.01(0.0-0.08) 0.01$ & 3.0 \\
\hline Iron & $0.08(0.0-1.76) 0.15$ & $0.02(0.0-0.44) 0.03$ & 2.7 & $0.02(0.0-0.26) 0.03$ & $0.01(0.0-0.06) 0.01$ & 2.0 \\
\hline
\end{tabular}

\subsection{Statistical analysis}

Statistical analyses, associated plots and confidence intervals were generated from the data using the R statistical and openair software packages (Carslaw and Ropkins, 2012).

\section{Results}

Indoor averages for $\mathrm{PM}_{2.5}$ when children were present at school (9am-3pm, weekdays) were 6.9 (range $<1.0-10.9$, SD 3.0) $\mu \mathrm{g} \mathrm{m}^{-3}$, which were significantly ( $p<0.001$ ) higher than when children were not present 6.4 (range 1.0-12.0, SD 1.9) $\mu \mathrm{g} \mathrm{m}^{-3}$. When children were at school, average indoor levels of $\mathrm{PM}_{10}$ were found to be significantly ( $\mathrm{p}<0.001$ ) higher than outdoor concentrations 30.1 (range 10.0-75.0, SD 9.0) $\mu \mathrm{g} \mathrm{m}^{-3}$ cf. 8.9 (range $<1.0-35.0$, SD 6.8) $\mu \mathrm{g} \mathrm{m}^{-3}$. Similarly, when children were absent from school, average indoor $\mathrm{PM}_{10}$ levels were significantly $(\mathrm{p}<0.001$ ) lower than when they were present and indoors 10.2 (5.0-30.0, SD 2.4) $\mu \mathrm{g} \mathrm{m}^{-3} \mathrm{cf}$. 30.1 (10.0-75.0, SD 9.0) $\mu \mathrm{g} \mathrm{m}^{-3}$. Fig. 2 presents time variation plots of indoor PM which show that both $\mathrm{PM}_{10}$ and $\mathrm{PM}_{2.5}$ levels increase on school days (Monday to Friday) around 7am and decrease around $4 \mathrm{pm}$.

During school hours the average indoor temperature was 19.4 (range 14.0-23.2, SD 1.6) ${ }^{\circ} \mathrm{C}$; with the indoor temperature below $18.0^{\circ} \mathrm{C}$, for $18 \%$ of the school day. Relative humidity was 60.8 (range 42.1-76.7, SD 6.5) \%. Inside the classroom during the school day, the $\mathrm{CO}_{2}$ average concentration was 887.8 (range 418.0-1626.0, SD 271.6) ppm, while the average $\mathrm{CO}_{2}$ concentration when the children were absent was $450.0 \mathrm{ppm}$ (range 423.0-503.0, SD 16.5). Fig. 3 shows ventilation rates from the classroom as calculated using measures of $\mathrm{CO}_{2}$. The average ventilation rate was 6.6 (range 3.8-74.9, SD 13.4) $\mathrm{Ls}^{-1}$ with ASHRARE's guideline of $8 \mathrm{Ls}^{-1}$ met only $38 \%$ of the time (ASHRAE, 1989).

The $\mathrm{NO}_{2}$ indoor average during school day was 56.4 (13.2-99.6, SD 13.9) $\mu \mathrm{g} \mathrm{m}^{-3}$. Weekday levels started increasing around 6am, peaking around $1 \mathrm{pm}$, before gradually decreasing. A time variation plot showed that indoor $\mathrm{NO}_{2}$ levels were higher on weekdays than weekends (Fig. S1).

Fig. 4 shows the 24 elements that were identified indoors on both the fine $\left(\mathrm{PM}_{2.5}\right)$ and coarse $\left(\mathrm{PM}_{10-2.5}\right)$ filters. As well as black carbon (BC), the main elements identified were sodium $(\mathrm{Na})$, silicon $(\mathrm{Si})$, chorine ( $\mathrm{Cl}$ ), aluminium ( $\mathrm{Al})$, calcium (Ca), magnesium (Mg), sulphur $(\mathrm{S})$, iron $(\mathrm{Fe})$, and potassium $(\mathrm{K})$. Table 1 shows that during the study period as for PM concentrations, it was found that the elemental concentrations were higher indoors than outdoors.

Fig. 5 shows that indoors three primary sources of $\mathrm{PM}_{2.5}$ and $\mathrm{PM}_{10}$ were identified using receptor modelling and apportionment of PM mass from the PMF chemical source profile data; these were classified as marine aerosol (sea salt), classroom dust and traffic PM. These sources were collectively found to explain $84 \%$ and $81 \%$ of the $\mathrm{PM}_{2.5}$ and $\mathrm{PM}_{10}$ mass, respectively. The remaining $\mathrm{PM}_{2.5}$ and $\mathrm{PM}_{10}$ proportion (16\%, $0.6 \mu \mathrm{g} \mathrm{m}^{-3}$ and $19 \%, 2 \mu \mathrm{g} \mathrm{m}^{-3}$ was likely to be associated with minor unmeasured components most likely organic matter (e.g.) fibers, skin cells.

Major elemental components of classroom dust were silicon, aluminium, calcium and iron, which indicate crustal matter origins and the primary traffic PM components were black carbon, sulphur along with some related crustal matter components (for $\mathrm{PM}_{10}$ ) indicative of a combination of tailpipe combustion emissions and road dust. The marine aerosol chemical profile contained most of the chlorine plus other sea salt components (magnesium, sulphur, potassium, calcium) in the appropriate relative ratios (Cohen, 1999; Lide, 1992; Malm et al., 1994) (sodium was below the analytical limit of detection across most of the samples and therefore was not included in the receptor modelling). Some aluminium and silicon was also associated in the sea salt profile most likely due to minor amounts of crustal matter covariant in the same air mass (e.g. wind driven dust).

Fig. 6 illustrates that the primary driver of indoor $\mathrm{PM}_{2.5}$ was from infiltration of outdoor pollutants inside, with traffic pollution (i.e. motor vehicle emissions and road dust), being the main contributor (56\%) of the three $\mathrm{PM}_{2.5}$ sources during class time. Classroom dust and marine aerosol made up $24 \%$ and $20 \%$ respectively of the three indoor $\mathrm{PM}_{2.5}$ sources. Over all samples (7 days per week, $24 \mathrm{~h}$ per day), the largest proportion of indoor $\mathrm{PM}_{10}$ was marine aerosol which made up $42 \%$, while traffic PM made up $31 \%$ and classroom dust, $27 \%$. However, when we considered the period of classroom occupancy (weekdays $9 \mathrm{am}-3 \mathrm{pm}$ ), then the crustal matter dust generated in the classroom (50\%) dominated $\mathrm{PM}_{10}$ concentrations, followed by marine aerosol (35\%) and traffic pollution (15\%).

When children and staff were not present in the classroom (weekends and non-school hours) classroom dust levels were lower 3.2 (range $<0.1-29.8$, SD 2.0) $\mu \mathrm{g} \mathrm{m}^{-3}$ than during school hours 8.5 (range $<0.1-36.5$, SD 9.4) $\mu \mathrm{g} \mathrm{m} \mathrm{m}^{-3}$. Also during school hours, concentrations were significantly ( $\mathrm{p}<0.001)$ higher in comparison to outdoor crustal matter (soil) 0.77 (range $<0.1-6.73$, SD 0.2) $\mu \mathrm{g} \mathrm{m}^{-3}$. Outdoor crustal matter had no obvious pattern and was most likely influenced by meteorological factors. Supplementary files (Fig. S2 and Fig. S3) show that classroom dust and outdoor crustal matter were unrelated.

\section{Discussion}

This study has measured the concentrations and sources of air pollution at an urban primary school. Identifying indoor pollutant sources is rarely done and is an important step in deciding on mitigation measures that may be taken to protect occupants from exposure. The primary driver of indoor $\mathrm{PM}_{2.5}$ at this school was from the infiltration of outdoor pollutants inside, with traffic PM, being the main contributor to indoor $\mathrm{PM}_{2.5}$. Mean indoor $\mathrm{PM}_{2.5}$ levels during school hours 6.9 

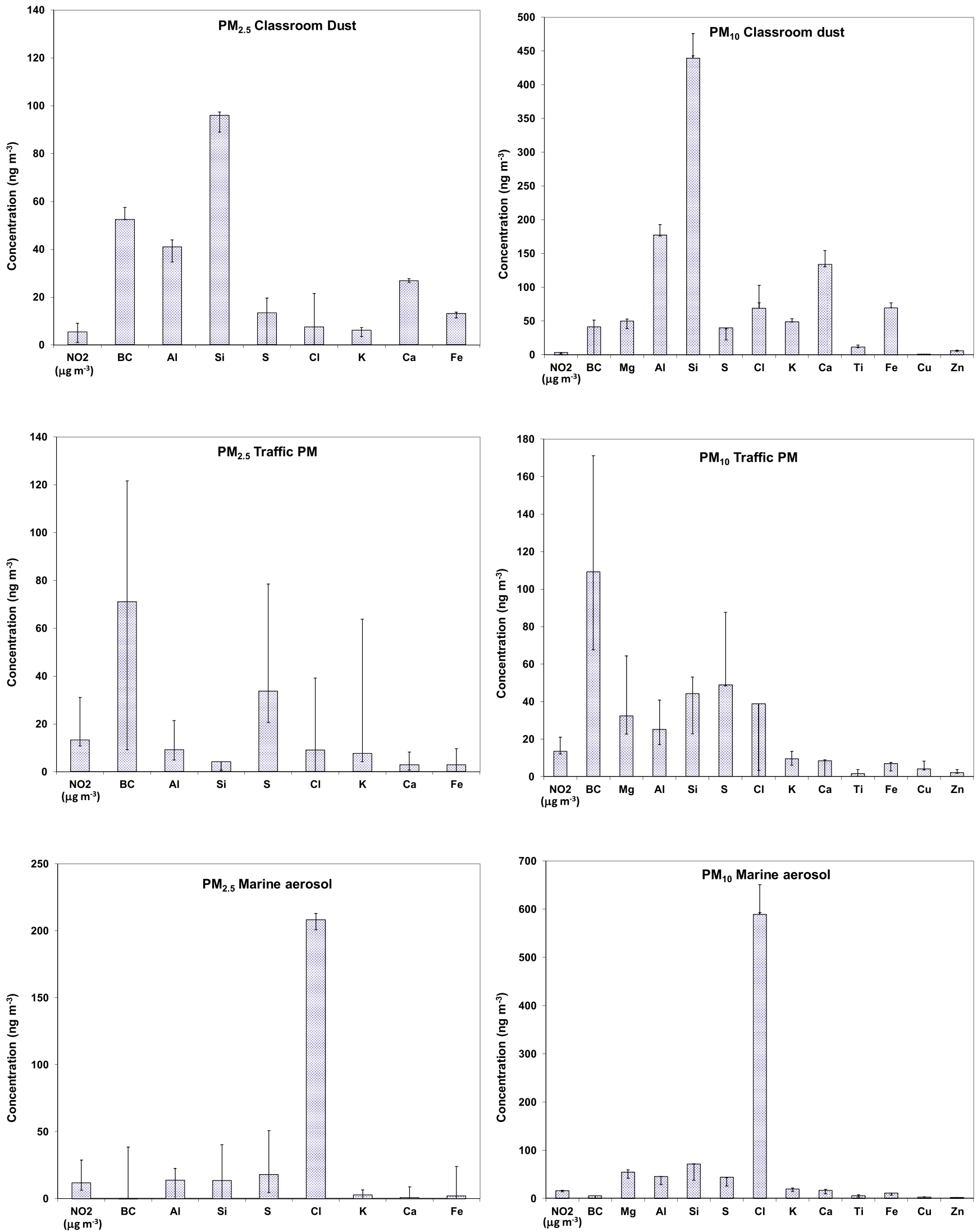

Fig. 5. Source profiles derived from PMF for indoor particulate matter. The error bars are the 5th and 95th confidence intervals derived from the modelling statistics. 

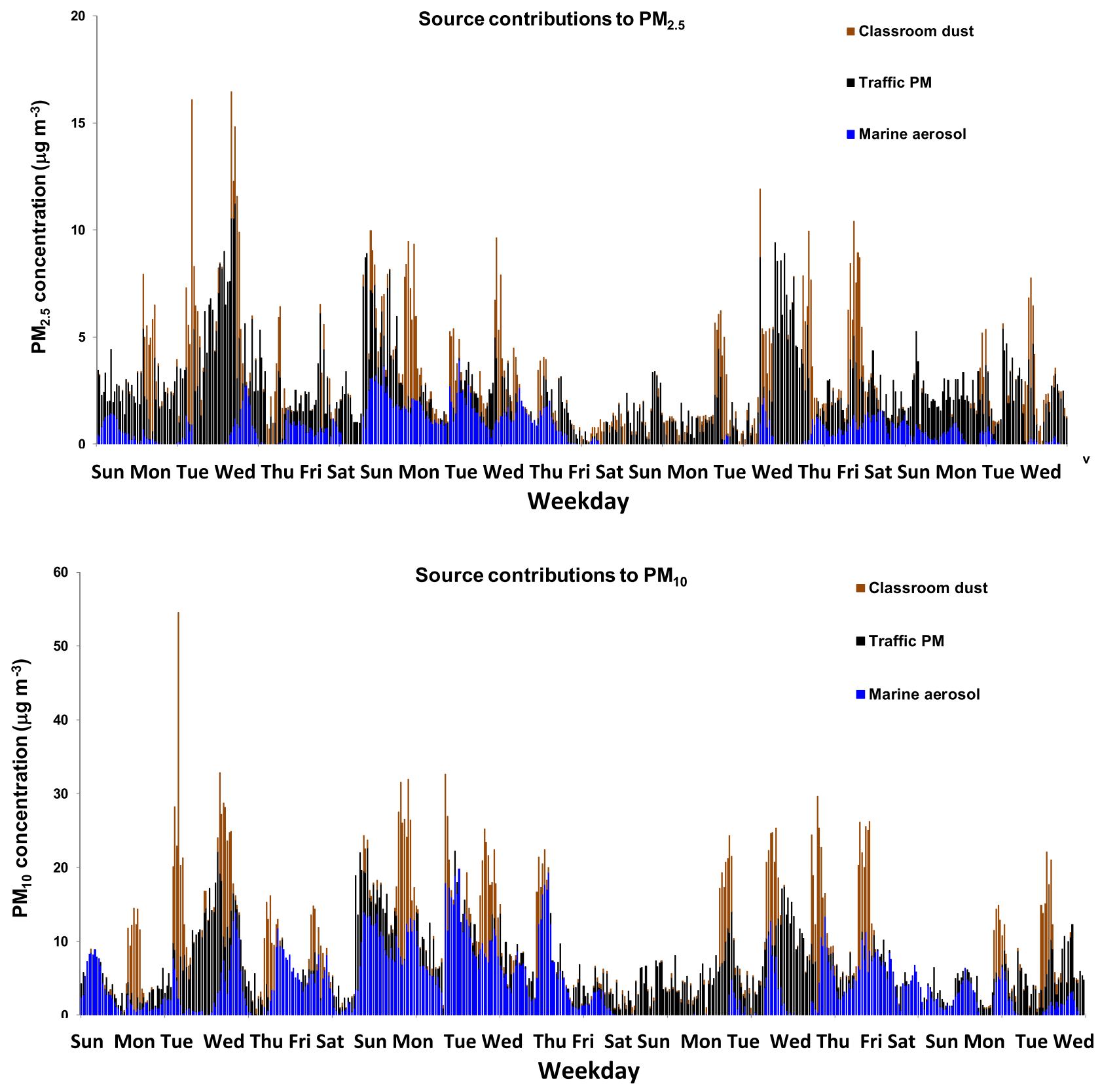

Fig. 6. Source contribution to indoor $\mathrm{PM}_{2.5}$ and $\mathrm{PM}_{10}$.

(range $<0.01-10.9$, SD 3.0) $\mu \mathrm{g} \mathrm{m}^{-3}$ were lower than those reported in 39 schools throughout Barcelona, Spain 37 (range 13-84) $\mu \mathrm{g} \mathrm{m}^{-3}$, but are comparable to outdoor levels in nine locations throughout New Zealand (range from 4.3 to $14.0 \mu^{-3} \mathrm{~m}^{-3}$ ) (Rivas et al., 2014; Ministry for the Environment, 2015). $\mathrm{NO}_{2}$ concentrations at this school were higher than those reported in the 39 schools in Barcelona 56.4 (13.2-99.6) c.f $30(5.1-69) \mu \mathrm{g} \mathrm{m} \mathrm{m}^{-3}$. It is well documented that trafficrelated $\mathrm{NO}_{2}$ concentrations surrounding major roadways are elevated (Karner et al., 2010; Rao et al., 2014). One explanation for the differences between $\mathrm{PM}_{2.5}$ and $\mathrm{NO}_{2}$ may be that despite being influenced by them, $\mathrm{PM}_{2.5}$ is not necessarily a good tracer of traffic emissions due to contributions from other sources; however, $\mathrm{NO}_{2}$ is a good tracer of traffic emissions (Rivas et al., 2014). The school has no indoor sources of $\mathrm{NO}_{2}$ and diurnal variations indicated $\mathrm{NO}_{2}$ levels increased around $6 \mathrm{am}$ to coincide with an increase in traffic; however we found only one peak in $\mathrm{NO}_{2}$, rather than two, as workers returned home. This is most likely because vehicles in the morning idled at the lights directly outside the school ( $38 \mathrm{~m}$ from classroom) and the evening traffic idled on the opposite side of the traffic-lights ( $115 \mathrm{~m}$ from classroom). Traffic related pollutants such as ultrafine particles, black carbon and total PM counts decrease rapidly with distance from the road (Zhu et al., 2002). This decay in concentrations with distance and downwind side is thought to be the same for $\mathrm{NO}_{2}$, with a $60-80 \%$ decrease from roadside concentrations within $100 \mathrm{~m}$ (Gilbert et al., 2003).

During school hours, average indoor $\mathrm{PM}_{10}$ concentrations were significantly higher in the classroom than $\mathrm{PM}_{10}$ concentrations found outdoors or when children were absent from the classroom. Other studies have reported similar findings with a study reporting median indoor particulate matter concentrations $\left(118.2 \mu \mathrm{g} \mathrm{m}^{-3}\right)$ higher than corresponding outdoor levels $\left(24.2 \mu \mathrm{g} \mathrm{m}^{-3}\right)$ in a German primary 
school (Fromme et al., 2008). Similar concentrations were confirmed in a Belgian survey (Stranger et al., 2008) and in a German study where Oeder and colleagues detected indoor $\mathrm{PM}_{10}$ concentrations more than five-fold higher than outdoor ones in six schools in Munich (Oeder et al., 2012). Indoor $\mathrm{PM}_{10}$ concentrations at this school were influenced by re-entrained soil into classrooms with indoor $\mathrm{PM}_{10}$ predominately composed of crustal (soil elements), which may have been brought in on children's footwear after playing outside and then were re-suspended as children moved about the classroom (Matic et al., 2017). These results mirror those found in a study conducted in a New Zealand school (Trompetter et al., 2018) and those in Germany (Fromme et al., 2008).

The average ventilation rate in the classroom in this study was 6.6 (range 3.8-74.9, SD 13.4) $\mathrm{Ls}^{-1}$ which was below ASHRAE's guideline of $8 \mathrm{Ls}^{-1}$ and only met the guideline $38 \%$ of the school day (ASHRAE, 1989). These results are similar to those found in other New Zealand schools, with one study reporting that three out of six classrooms had $\mathrm{CO}_{2}$ levels above $1000 \mathrm{ppm}$ for 50 percent of the school day (Wang et al., 2013). Higher ventilation rates are associated with reduced absences (Fisk, 2017; Wargocki et al., 2004; Gaihre et al., 2014; Shendell et al., 2004) and increased performance on computerised English tests in schools (Bako-Biro et al., 2012).

Although this study only involved one school and one classroom at the school, it was an intensive study that identified the composition and concentrations of sources of air pollutants on an hourly basis. Previous indoor air quality studies are generally based on particle mass concentrations, without the identification of the main pollutant sources, hence this study is an important first step towards disentangling source contributions in the indoor environment. $\mathrm{NO}_{2}$ was only measured indoors as our interest was in the children's indoor exposure to $\mathrm{NO}_{2}$ and since there were no indoor sources then it was assumed all $\mathrm{NO}_{2}$ would be from outdoors (traffic emissions being the predominant source), as gases and ultrafine particles are more efficient at infiltrating indoor environments than larger fractions (El Orch et al., 2014).

The study provides useful insights into sources of air pollution at an urban New Zealand school. Mitigation measures to improve indoor air quality need further investigation, but may include; behavioural changes to improve ventilation, improvement of cleaning actions; the replacement of carpets by smooth flooring panels, the adequacy of occupational density and promotion of more class breaks; and structural measures such as the installation of air purifiers (Sa et al., 2017). In addition, the placement of new schools, should consider the proximately to main roads and the location of ventilating windows or intakes to ensure children's health is not compromised by indoor air exposure at school.

\section{Conclusion}

Our results demonstrate that the main source responsible for indoor $\mathrm{PM}_{2.5}$ concentrations measured at this school was from the infiltration of traffic pollution. Indoor levels of $\mathrm{PM}_{10}$ were significantly higher than outdoor levels with the increased $\mathrm{PM}_{10}$ in classrooms predominately from crustal sources, thought to be soil tracked in from outside on footwear and re-suspended during activities within classrooms. In addition, this classroom had poor ventilation with ASHRAES guideline of $8 \mathrm{Ls}^{-1}$ met only $38 \%$ of the school day. There is a need for mitigation strategies to reduce exposure to indoor air pollution at schools, such as improved cleaning methods, reducing the use of carpet in schools and improved ventilation. The findings and recommendations from this study will be applicable to many other schools and public buildings that have high foot traffic and indicate that poor air quality in New Zealand schools should be more closely monitored.

\section{Funding}

This study was funded by the Building Research Association of New Zealand (BRANZ).

\section{Appendix A. Supplementary data}

Supplementary data to this article can be found online at https:// doi.org/10.1016/j.apr.2018.09.006.

\section{References}

Almeida, S.M., Canha, N., Silva, A., do Carmo Freitas, M., Pegas, P., Alves, C., Evtyungina, M., Pio, C.A., 2011. Children exposure to atmospheric particles in indoor of Lisbon primary schools. Atmos. Environ. 45 (40), 7594-7599. https://doi.org/10.1016/j. atmosenv.2010.11.052.

American Society of Heating and Air Conditioning Engineers, 1989. Ventilation for Acceptable Air Quality. ASHRAE 62 -1989.

Amram, O., Abernethy, R., Brauer, M., Davies, H., Allen, R., 2011. Proximity of public elementary schools to major roads in Canadian urban areas. Int. J. Health Geogr. 10 (68). https://doi.org/10.1186/1476-072X-10-68.

Ancelet, T., Davy, P.K., Trompetter, W.J., Markwitz, A., Weatherburn, D.C., 2011. Carbonaceous aerosols in an urban tunnel. Atmos. Environ. 45, 4463-4469.

Ancelet, T., Davy, P.K., Mitchell, T., Trompetter, W.J., Markwitz, A., Weatherburn, D.C., 2012. Identification of Particulate Matter Sources on an hourly time scale in a wood burning community. Environ. Sci. Technol. 46, 4767-4774.

Annegarn, H.J., Cahill, T.A., Sellschop, J.F.P., Zucchiatti, A., 1988. Time sequence particulate sampling and nuclear analysis. Phys. Scripta 37, 282-290.

Annesi-Maesano, I., Baiz, N., Banerjee, S., Rudnai, P., Rive, S., SINPHONE Group, 2013. Indoor air quality and sources in schools and related health effects. J. Toxicol. Environ. Health B 16 (8), 491-550.

Bako-Biro, Z., Clements-Croome, D.J., Kochhar, N., Awbi, H.B., Williams, M.J., 2012. Ventilation rates in schools and pupils' performance. Build. Environ. 48, 215-223.

Bennett, W.D., Zeman, K.L., Jarabek, A.M., 2008. Nasal contribution to breathing and fine particle deposition in children versus adults. J. Toxicol. Environ. Health A 71 (3), 227-237.

Brook, R.D., 2008. Cardiovascular effects of air pollution. Clin. Sci. (Lond.) 115 (6), 175-187. https://doi.org/10.1042/CS20070444.

Brown, S.G., Eberly, S., Paatero, P., Norris, G.A., 2015. Methods for estimating uncertainty in PMF solutions: examples with ambient air and water quality data and guidance on reporting PMF results. Sci. Total Environ. 518, 626-635.

Carslaw, D.C., Ropkins, K., 2012. Openair — an R Package for Air Quality.

CEN Standard EN15251, 2007. Indoor Environmental Input Parameters for Design and Assessment of Energy Performance of Buildings Addressing Indoor Air Quality, Thermal Environment, Lighting and Acoustics Bruxelles. European committee for Standardisation.

Chen, B.Y., Jasmine Chao, H., Wu, C.F., Kim, H., Honda, Y., Guo, Y.L., 2014. High ambient Cladosporium spores were associated with reduced lung function in schoolchildren in a longitudinal study. Sci. Total Environ. 481, 370-376. http://doi.org/10. 1016/j.scitotenv.01.078.

Clausen, G., Toftum, J., Bekö, G., 2009. Indoor Environment and Children's Health (IECH) - an ongoing epidemiological investigation on the association between indoor environmental factors in homes and kindergartens and children's health and wellbeing. Curr. Probl. Cardiol. 40 (5), 207-238. https://doi.org/10.1016/j.cpcardiol.2015.01. 003. Epub 2015 Jan 3.

Daisey, J.M., Angell, W.J., Apte, M.G., 2003. Indoor air quality, ventilation and health symptoms in schools: an analysis of existing information. Indoor Air 13 (1), 53-64.

de Gennaro, G., Dambruoso, P.R., Loiotile, A.D., Di Gilio, A., Giungato, P., Tutino, M., Marzocca, A., Mazzone, A., Palmisani, J., Porcelli, F., 2014. Indoor air quality in schools. Environ. Chem. Lett. 12 (4), 467-482. https://doi.org/10.1007/s10311-0140470-6.

Cohen, D., 1999. Accelerator based ion beam techniques for trace element aerosol analysis. In: Landsberger, S., Creatchman, M. (Eds.), Elemental Analysis of Airborne Particles. Gordon and Breach Science Publishers, Amsterdam.

D'Alessandro, A., Nava, S., Van Ham, R., Adriaens, A., Lucarelli, F., Marcazzan, G., Prati, P., Valli, G., Veechi, R., Zucchiatti, A., et al., 2004. PIXE and ToF-SIMS analysis of streaker samplers filters. Nucl. Instrum. Meth. Phys. Res. 222 (1-2), 261-269. https://doi.org/10.1016/j.nimb.2004.02.014.

El Orch, Z., Stephens, B., Waring, M.S., 2014. Predictions and determinants of size-resolved particle infiltration factors in single-family homes in the US. Build. Environ. 74, 106-118.

Ferreira, A.M., Cardoso, M., 2014. Indoor air quality and health and schools. J. Bras. Pneumol. Publicacao Of. Soc. Brasil. Pneumol. E Tisilogia 40 (3), 259-268.

Filippi, E., Prati, P., Zucchiatti, A., Lucarelli, F., Ariola, V., Corvisiero, P., 1999. Hourly measurement of particulate concentrations with Streaker samplers and optical monitoring. Nucl. Instrum. Meth. Phys. Res. B 150, 370.

Fisk, W.J., 2017. The ventilation problem in schools: literature review. 27 (6), 1039-1051. https://doi.org/10.1111/ina.12403.

Forns, J., Dadvand, P., Foraster, M., Alvares-Pedrerol, M., Rivas, I., Lopez-Vicente, M., Suades-Gonzalez, E., Garcia-Esteban, R., Esnaola, M., Cirach, M., Grellier, J., Basagaña, X., Querol, X., Guxens, M., Nieuwenhuijsen, M.J., Sunyer, J., 2016. Trafficrelated air pollution, noise at school, and behavioural problems in Barcelona schoolchildren: a cross-sectional study. Environ. Health Perspect. 124 (4), 529-535.

Forouzanfar, M.H., Alexander, L., Anderson, H.R., Bachman, V.F., Biryukov, S., Brauer, M., et al., 2015. Global, regional, and national comparative risk assessment of 79 behavioural, environmental and occupational, and metabolic risks or clusters of risks in 188 countries, 1990-2013: a systematic analysis for the global burden of disease study. Lancet 386 (10010), 2287-2323.

Franklin, B.A., Brook, R., Arden, Pope 3rd., C., 2015. Air Pollution and Cardiovascular 
Disease.

Fromme, H., Diemer, J., Dietrich, S., Cyrys, J., Heinrich, J., Lang, W., Kiranoglu, M., Twardella, D., 2008. Chemical and morphological properties of particulate matter (PM10, PM2.5) in school classrooms and outdoor air. Atmos. Environ. 42, 6597-6605.

Fuentes-Leonarte, V., Ballester, F., Tenias, J.M., 2009. Sources of indoor air pollution and respiratory health in preschool children. J. Environ. Publ. Health 2009 (727516). https://doi.org/10.1155/2009/727516.

Gaihre, S., Semple, S., Miller, J., Fielding, S., Turner, S., 2014. Classroom carbon dioxide concentration, school attendance, and educational attainment. J. Sch. Health 84 (9), 569-574. https://doi.org/10.1111/josh.12183.

Gilbert, N., Woodhouse, S., Stieb, D.M., Brook, J.R., 2003. Ambient nitrogen dioxide and distance from a major highway. Sci. Total Environ. 312 (1-3), 43-46.

Jacobs, J., Borras-Santos, A., Krop, E., Taubel, M., Leppanen, H., HaverinsenShaughnessey, U., Pekkanen, J., Hyvärinen, A., Doekes, G., Zock, J.P., Heederik, D. 2014. Dampness, bacterial and fungal components in dust in primary schools and respiratory health in schoolchildren across Europe. Occup. Environ. Med. 71 (10), 704-712.

Karner, A.A., Eisingerm, D.S., Niemeier, D.A., 2010. Near-road air quality: synthesizing the findings from real-world data. Environ. Sci. Technol. 44 (14), 5335-5344.

Kostinen, K., Kotzias, D., Kephalopoulos, S., Schlitt, C., Carrer, P., Jantunen, M., Kirchner, S., McLaughlin, J., Molhave, L., Fernandes, E.O., Seifert, B., 2008. The INDEX project: executive summary of a European Union project on indoor air pollutants. Allergy 63 (7), 810-819.

Kulkarni, N., Grigg, J., 2008. Effect of air pollution on children. Paediatr. Child Health 18, 238-243.

Landsberger, S., Creatchman, M., 1999. Elemental analysis of airborne particles. In: Adv. Environ., Ind. Process Control Technol, first ed. .

Lide, D.R., 1992. CRC Handbook of Chemistry and Physics, $73^{\text {rd }}$ Edition. CRC Press, Boca Raton, FL, pp. 2544 Abundance of elements in the Earth's crust and the sea s14-17.

MacIntyre, E.A., Gehring, U., Mölter, A., Fuertes, E., Klümper, C., Krämer, U., et al., 2014 Air pollution and respiratory infections during early childhood: an analysis of 10 European birth cohorts within the ESCAPE Project. Environ. Health Perspect. 122 (1), $107-113$.

Maenhaut, W., Malmqvist, K.G., 2001. Particle induced X-ray emission analysis. In: Grieken, R.V. (Ed.), Handbook of X-ray Spectrometry, 2 ed. Marcel Dekker Inc, Antwerp.

Malm, W.C., Sisler, J.F., Huffman, D., Eldred, R.A., Cahill, T.A., 1994. Spatial and seasonal trends in particle concentration and optical extinction in the United States. J. Geophys. Res. Atmos. 99, 1347-1370.

Mathiesen, K., 2015. Where Is the World's Windiest City? Spoiler Alert: It's Not Chicago. The Guardian. (15 October).

Matic, B., Rakic, E., Jovanovic, V., Dejanovic, S., Djonovic, N., 2017. Key factors determining indoor air $\mathrm{PM}_{10}$ concentrations in naturally ventilated primary schools in Belgrade, Serbia. ZDR Varst. 56 (4), 227-235.

Maxwell, J.A., Teesdale, W.J., Cambell, J.L., 1995. The Guelph PIXE software package II Nucl. Instrum. Meth. B. 95, 407.

McConnell, R., Islam, T., Shankardass, K., Jerrett, M., Lurmann, F., Gilliland, F., Gauderman, J., Avol, E., Künzli, N., Yao, L., Peters, J., Berhane, K., 2010. Childhood incident asthma and traffic-related air pollution at home and school. Environ. Health Perspect. 118 (7), 1021-1026 pmid:20371422.

McIntosh, J., 2011. The Indoor Air Quality in 35 Wellington Primary Schools. (Master). Victoria University of Wellington, Wellington, New Zealand.

Mendell, M.J., Heath, G.A., 2005. Do indoor pollutants and thermal conditions in schools influence student performance? A critical review of the literature. Indoor Air 15 (1), 67.

Mendell, M.J., Eliseeva, E.A., Davies, M.M., Spears, M., Lobscheid, A., Fisk, W.J., Apte, M.G., 2013. Association of classroom ventilation with reduced illness absence: prospective study in California elementary schools. Indoor Air 23 (6), 515-528.

Ministry for the Environment. 2015. http://www.stats.govt.nz/browse for stats/ environment/environmental-reporting-series/environmental-indicators/Home/Air/ pm2_5-concentrations.aspx accessed September 2017.

Ministry of Education, 2017. Designing Quality Learning Spaces: Indoor Air Quality and Thermal Comfort.

Moonie, S.A., Sterling, D.A., Figgs, L., Castro, M., 2006. Asthma status and severity affects missed school days. J. Sch. Health 76 (1), 18-24. https://doi.org/10.1111/j.17461561.2006.00062.x

Morgan, M.K., Wilson, N.K., Chuang, J.C., 2014. Exposures of 129 preschool children to organochlorines, organophosphates, pyrethroids, and acid herbicides at their homes and daycares in North Carolina. Int. J. Environ. Res. Publ. Health 11 (4), 3743-3764. http://doi.org/10.3390/ijerph110403743.

Nazaroff, W.W., 2004. Indoor particle dynamics. Indoor Air Suppl. 14 (Suppl. 7), $175-183$.

Norris, G., Duvall, R., Brown, S., Bai, S., 2014. EPA Positive Matrix Factorization (PMF) 5.0 Fundamentals and User Guide.

Oeder, S., Dietrich, S., Weichenmeier, I., Schober, W., Pusch, G., Jörres, R.A., Schierl, R., Nowak, D., Fromme, H., Behrendt, H., Buters, J.T., 2012. Toxicity and elemental composition of particulate matter from outdoor and indoor air of elementary schools in Munich, Germany. Indoor Air 22, 148-158.

Paatero, P., Hopke, P.K., 2009. Rotational tools for factor analytical models. J. Chemometr. 23 (2), 91-100.

Polissar, A.V., Hopke, P.K., Paatero, P., Malm, W.C., Sisler, J.F., 1998. Atmospheric aerosol over Alaska: 2. Elemental composition and sources. J. Geophys. Res. 103 (D15), 19045-19057.

Porta, D., Narduzzi, S., Badaloni, C., Bucci, S., Cesaroni, G., Colelli, V., Davoli, M., Sunyer, J., Zirro, E., Schwartz, J., Forastiere, F., 2016. Air pollution and cognitive development at age 7 in a prospective Italian birth cohort. Epidemiology 27 (2), 228-236.

Rao, P., Hutyra, L.R., Raciti, S.M., Templer, P.H., 2014. Atmospheric nitrogen inputs and losses along an urbanization gradient from Boston to Harvard Forest, MA. Biogeochemistry 121 (1), 229-245.

Raysoni, A.U., Sarnat, J.A., Sarnat, S.E., Garcia, J.H., Holguin, F., Luevano, S.F., Li, L.L., 2011. Binational school-based monitoring of traffic-related air pollutants in el Paso, Texas (USA) and Ciudad Juarez, Chihuahua (Mexico). Environ. Pollut. Oct. 159 (10), $2476-2486$.

Rivas, I., Viana, M., Moreno, T., Pandolfi, M., Amato, F., Reche, C., Bouso, M., AlvarezPadrerol, M., Alastuey, A., Sunyer, J., Querol, X., 2014. Child exposure to indoor and outdoor air pollutants in schools in Barcelona, Spain. Environ. Int. 69, 200-212.

Sa, J.P., Branco, P.T.B.S., Alvim-Ferraz, M.C.M., Martins, F.G., Sousa, S.I.V., 2017. Evaluation of low-cost mitigation measures implemented to improve air quality in nursery and primary schools. Int. J. Environ. Res. Publ. Health 14 (6), 585.

Shendell, D.G., Prill, R., Fisk, W.J., Apte, M.G., Blake, D., Faulkner, D., 2004. Associations between classroom $\mathrm{CO}_{2}$ concentrations and student attendance in Washington and Idaho. Indoor Air 14 (5), 333-341.

Simoni, M., Annesi-Maesano, I., Sigsgaard, T., Norbäck, D., Wieslander, G., Nystad, W., Canciani, M., Sestini, P., Veigi, G., 2010. School air quality related to dry cough, rhinitis and nasal patency in children. Eur. Respir. J. 35 (4), 742-749.

Sofuoglu, S.C., Aslan, G., Inal, F., Sofuoglu, A., 2011. An assessment of indoor air concentrations and health risks of volatile organic compounds in three primary schools. Int. J. Hyg Environ. Health 214 (1), 36-46. http//doi.org/10.1111/1753-0407. 12325.

Song, X.H., Polissar, A.V., Hopke, P.K., 2001. Sources of fine particle composition in the northeastern US. Atmos. Environ. 35, 5277-5286.

Standards Association of New Zealand, 1990. New 4303:1990, Ventilation for Acceptable Indoor Air Quality New Zealand Standard. Standards Association of New Zealand.

Stanek, L.W., Sacks, J.D., Dutton, S.D., Dubois, J.B., 2011. Attributing health effects to apportioned components and sources of particulate matter: an evaluation of collective results. Atmos. Environ. 45 (32), 5655-5663.

Stranger, M., Potgieter-Vermaak, S.S., Van Grieken, R., 2008. Characterization of indoor air quality in primary schools in Antwerp, Belgium. 18 (6), 454-463.

Sunyer, J., Esnaola, M., Alvarez-Pedrerol, M., Forns, J., Rivas, I., Lopez-Vicente, M., Suades-González, E., Foraster, M., Garcia-Esteban, R., Basagaña, X., Viana, M., Cirach, M., Moreno, T., Alastuey, A., Sebastian-Galles, N., Nieuwenhuijsen, M., Querol, X., 2015. Association between traffic-related air pollution in schools and cognitive development in primary school children: a prospective cohort study. PLoS Med. 12 (3), e1001792.

Taras, H., Potts-Datema, W., 2005. Childhood asthma and student performance at school. J. Sch. Health 75 (8), 296-312.

Trompetter, W.J., Markwitz, A., Davy, P.K., 2005. Air particulate research capability at the New Zealand ion beam analysis facility using PIXE and IBA techniques. Int. J. PIXE 15, 249-255.

Trompetter, W.J., Boulic, M., Ancelet, T., Garcia-Ramirez, J.C., Davy, P.K., Wang, Y., Phipps, R., 2018. The effect of ventilation on air particulate matter in school classrooms. J. Build. Eng. 18, 164-171.

Tunno, B.J., Dalton, R., Cambal, L., Holguin, F., Lioy, P., Clougherty, J.E., 2016. Indoor source apportionment in urban communities near industrial sites. Atmos. Environ. 139, 30-36. https://doi.org/10.1016/j.atmosenv.2016.04.039.

Uzoigwe, J.C., Prum, T., Bresnahan, E., Garelnabi, M., 2013. The emerging role of outdoor and indoor air pollution in cardiovascular disease. N. Am. J. Med. Sci. 5 (8), 445-453. http://doi.org/10.4103/1947-2714.117290.

Wang, Y., Boulic, M., Phipps, R., Plagmann, M., Cunningham, C., Theobald, C., HowdenChapman, P., Baker, M., 2013. Effects of solar collectors on indoor air quality in junior classrooms in winter. In: Building a Better New Zealand Conference, Auckland, New Zealand.

Wargocki, P., Wyon, D.P., Fanger, P.O., 2004. The performance and subjective responses of call-centre operators with new and used supply air filters as two outdoor air supply rates. Indoor Air 14, 7-16.

Zhou, S., Davy, P.K., Wang, X., Cohen, J.B., Liang, J., Huang, M., Fan, Q., Chen, W., Chang, M., Ancelet, T., Trompetter, W.J., et al., 2016. High time-resolved elemental components in fine and coarse particles in the Pearl River Delta region of Southern China: dynamic variations and effects of meteorology. Sci. Total Environ. 572, 634-648.

Zhu, Y., Hinds, W.C., Kim, S., Shen, S., Sioutas, C., 2002. Study of ultrafine particles near a major highway with heavy-duty diesel traffic. Atmos. Environ. 36 (27), 4323-4335. 